\title{
Investigation on mesophilic anaerobic co-digestion of community waste and cow dung: effect of operating parameters
}

\begin{abstract}
Management of waste is a key concern in several communities in Ghana. The exponential growth in waste generation imposes serious threats such as environmental pollution, health risk and scarcity of dumping site to our society. A large variety of organic rich materials inherent in this waste have high potential to be treated by the use of anaerobic digestion. In this study, eight (8) Laboratory scale biodigesters were used for the anaerobic co-digestion of household and market waste with cow dung as inoculum, controlled at a $\mathrm{pH}$ range of 6.53-7.04 and at a mesophilic temperature of $35 \pm 2^{\circ} \mathrm{C}$. The study was also conducted in batch mode at a hydraulic retention time of 21 days. The anaerobic co-digestion process was developed and optimized at varying feedstock to inoculum ratio to determine the potential biogas yield from each proportion. The results obtained indicate sample S8, containing market waste and inoculum in the ratio of 6:1 produced the optimum concentration of methane $(51 \% \mathrm{v} / \mathrm{v}$ biogas) while the least was recorded by sample S2 primarily made up of market waste. ANOVA results show that the concentration of methane produced from the substrate is significantly affected by the hydraulic retention time and $\mathrm{pH}$ value of the anaerobic digestion process.
\end{abstract}

Keywords: waste management, organic waste, anaerobic digestion, volatile solids, methane, central composite rotatable design
Volume 4 Issue 6 - 2019

\author{
KO Ansah Amano,' E Appiah-Danquah, ${ }^{2} \mathrm{E}$ \\ Adom, ${ }^{3}$ AG Ntiri-Asiedu, ${ }^{4}$ ES Amoamah, ${ }^{3}$ DK \\ Nkansah ${ }^{3}$ \\ 'Department of Systems Engineering and Plant Safety, Institute \\ of Instrumental and Environmental Technology, Otto von \\ Guericke Universität, Germany \\ ${ }^{2}$ Department of Petroleum Engineering, Kwame Nkrumah \\ University of Science and Technology, Ghana \\ 'Department of Chemical Engineering, Biotechnology \\ Laboratory, Kwame Nkrumah University of Science and \\ Technology, Ghana \\ ${ }^{4}$ The Brew Hammond Energy Centre, College of Engineering, \\ Kwame Nkrumah University of Science and Technology, Ghana
}

Correspondence: KO Ansah Amano, Department of Systems Engineering and Plant Safety, Institute of Instrumental and Environmental Technology, Otto von Guericke Universität 39106, Magdeburg, Germany, Tel +49I521303707I, Email kofi.aman@st.ovgu.de,owusuaman@rocketmail.com

Received: December 12, 2019 | Published: December 20, 2019
Abbreviations: $\mathrm{AD}$, anaerobic digestion; VFA, volatile fatty acid; HRT, hydraulic retention time; $\mathrm{C} / \mathrm{N}$, carbon to nitrogen ratio; OLR, organic loading rate; LS, low solid; MS, medium solid; HS, high solid; BMP, biochemical methane potential; TS, total solids; MC, moisture content; VS, volatile solids; AC, ash contents; CCRD, central composite rotatable designs; RSM, response surface methodology; ANOVA, analysis of variance; CL, confidence level

\section{Introduction}

Waste management is a major challenge in several communities in Ghana. The exponential growth in waste production imposes serious threats to our society like environmental pollution, and health risk. The baseline environmental sanitation survey in 2007/2008 reported, about $76 \%$ of households in Ghana rely on improper waste collection and disposal methods, with only $5 \%$ employing house to house collection services. ${ }^{1}$ Averagely, 365,000 tonnes waste is generated in Kumasi with a per capita of $0.6 \mathrm{~kg} /$ day and a population density of 6342 persons per square kilometre. ${ }^{2}$ Further study by Miezah et al. ${ }^{3}$ also indicates Kumasi metropolis has the highest waste generation rate of $0.75 \mathrm{~kg} /$ person/day which is slightly greater than that of the capital city Accra, $0.74 \mathrm{~kg} /$ person/day. ${ }^{3}$ This quantity of waste generation is estimated to the highest among the cities in Ghana Several studies imply much of the municipal solid waste generated in developing countries are largely from households (55-80\%), followed by commercial or market areas (10-30\%) with varying quantities from industries, streets and the like. ${ }^{3}$ An estimated amount of $64 \%$ solid waste have been identified to be biodegradable with the remaining 36\% which includes plastics, glass, among others being non-biodegradable.

Currently, biodegradable materials accompanying waste generated in most municipalities and households in Ghana are treated by landfills or used as animal feedstock. This has attracted public attention due to the serious health and environmental effects associated with waste at the landfills. Improper management and control of landfills increases the likelihood for occurrence of fires and explosions, vegetation damage, unpleasant smell, groundwater pollution, air pollution and global warming. ${ }^{4}$ There is high possibility of ground water pollution due to the percolation of leachate in the subsoil..$^{5}$ Leachate from a landfill is characterized by high organic and inorganic pollutant concentrations and is extremely toxic to the environment. ${ }^{6}$ Most waterbodies especially boreholes around landfill vicinities get polluted by leachate and require certain levels of treatment before use. $^{7}$ The presence of toxic trace elements in high concentrations above required standards causes heavy pollution of the water sources and soil of surrounding agricultural areas. ${ }^{8}$ By considering all the above facts, there is the need for separating biodegradable organic waste from the non-biodegradable waste and treating them with a much environmentally friendly method. In most cases, the scope of 
dealing with the biodegradable fraction of the waste is narrowed to the use of eco-friendly anaerobic digestion for treatment because it has proven to be promising method for waste reduction and energy recycling.

A wide variety of organic rich materials inherent in this waste have high potential to be treated by the use of anaerobic digestion. ${ }^{9}$ Some categories of suitable organic materials used as substrate and digested under anaerobic conditions with the aid of microorganism are domestic organic waste, communal sewage sludge, liquid or solid manure, crops and industrial food waste. ${ }^{10}$ Anaerobic digestion approach has emerged as one of the most eco-friendly and potential solution for organic wastes management, nutrient production and clean and environmentally safe energy. Studies indicate food waste disposal through anaerobic digestion to produce biogas is eco-friendly and also puts the waste to better use. ${ }^{11}$ Nayono also reports anaerobic digestion of biodegradable solid waste can be regarded as an alternative choice to enhance the environmental condition caused by organic solid waste and at the same serve as an environmentally friendly energy. ${ }^{12}$

According to International Energy Agency report, the global energy demand is growing rapidly with approximately $88 \%$ of this being met by fossil fuels. ${ }^{13}$ Utilization of anaerobic digestion (AD) process have been an effective technology to improve energy security and reduce environmental pollution. ${ }^{14}$ Biogas, which is mainly a mixture of methane $\left(\mathrm{CH}_{4}\right)$ and carbon dioxide $\left(\mathrm{CO}_{2}\right)$ is generated during the anaerobic digestion process. ${ }^{15}$ Generally, biogas consist of $60-70 \%$ methane, $20-30 \%$ carbon dioxide, $0-3 \%$ nitrogen, $0-1 \%$ hydrogen, and $0-1 \%$ hydrogen sulphide. ${ }^{16}$ The $\mathrm{AD}$ process consists of four main stages which results in the complete biodegradation of the organic components by different types of microorganisms. These stages are hydrolysis, acidogenesis, acetogenesis, and the methanogens. The final stage, methanogenesis, is where carbon dioxide $\left(\mathrm{CO}_{2}\right)$ generated by the previous processes reacts with hydrogen present in the reactor to produce methane by hydrogenotrophic methanogens while acetates are also converted to methane and carbon dioxide. ${ }^{17}$

In a single stage biogas digester, the waste materials are charged simultaneously, and all the four processes are allowed to occur on the same digester. During the hydrolysis stage of the AD process, complex polymers which are inaccessible to microorganisms are broken down into their constituent monomers. ${ }^{18,19}$ Organic macromolecules produced by the hydrolysis process can then be consumed by acidogenic bacteria. The acidogenic bacteria then produce intermediate volatile fatty acids (VFAs) which constitute a class of organic acids such as acetates and larger organic acids such as propionate and butyrate and are in a ratio varying from approximately 75:15:10 to 40:40:20. ${ }^{20}$ The $\mathrm{pH}$ of the aforementioned processes or stages is an important operating parameter to maintain at an optimum range due to its high influence on VFA yield and distribution within the digester. ${ }^{21}$ VFA acidification causes $\mathrm{pH}$ values to decrease and is widely reported to be a cause for digester failure. ${ }^{22}$ During the acidification process, $\mathrm{pH}$ value reduces to $4 .{ }^{23,24}$ In the next stage, acetogenesis process, higher VFAs and other intermediates produced by previous acidogenesis are converted into acetate, with hydrogen also being produced. ${ }^{19}$ Methanogenic microorganisms convert all accessible intermediates as rapidly as they appear mainly into methane and carbon dioxide during the final stage of anaerobic digestion known as methanogenesis. In spite of this, if the methanogenic microorganisms are not present in suitable counts or their growth is being inhibited by unfavourable environmental conditions, they will not consume the produced acids at a required rate thereby causing an increase in the concentration of volatile acids. Methanogenic microorganisms are a group of obligate anaerobic archaea; as an indication to the acute sensitivity of methanogenic microorganisms to oxygen, it was found that $99 \%$ of Methanococcus voltae and Methanococcus vannielli cells had been killed within ten hours upon exposure to oxygen. ${ }^{25}$ In a batch digester or reactor the end of methanogenic activity is determined when there is little or an insignificant amount of biogas production. Most researchers report that the rate-limiting step for complex organic substrates is the hydrolysis stage. This is due to the formation of toxic by-products (complex heterocyclic compounds) or non-desirable volatile fatty acids (VFA) which occurs during the hydrolysis stage. ${ }^{26}$ On the contrary, methanogenesis is known to be the rate-limiting step for easily biodegradable substrate. ${ }^{27}$

Several parameters within an $\mathrm{AD}$ process can have positive or negative effects on its physical environment and production efficiency. ${ }^{28}$ These parameters include temperature, hydraulic retention time (HRT), carbon to nitrogen ratio $(\mathrm{C} / \mathrm{N})$, solid to liquid content, $\mathrm{pH}$ value, and the organic loading rate (OLR). ${ }^{29} \mathrm{~A}$ sudden change in the said parameters could cause adverse effects during the anaerobic digestion process. ${ }^{30}$ According to Sambo et al. improper control of the operating parameter can cause an inhibition of the AD process. ${ }^{31}$ To prevent such inhibition, it is necessary to ensure the operating parameters are favourable for the bacteria involved in the digestion process. ${ }^{32}$ To obtain optimum methane yield, these parameters must be varied at a desired range.$^{33}$ It is however important to take into consideration the type of feedstock used for the AD process. ${ }^{34}$ The three (3) different ranges of total solid content commonly used for AD processes are low solid (LS) which contains less than $10 \%$ total solids, medium solid (MS) from $15-20 \%$ and high solid systems (HS) also ranging from 22-40\%. By increasing the concentration of the total solids, the biological working volume of the respective digester used for the biogas production also decreases due to low water requirement. ${ }^{35}$ Similarly, biogas production also depends on the volatile solid (VS) content of the feedstock. Organic materials such as communal and market waste with high lignin influences the biological activity and degradability of the substrate. ${ }^{36}$

Methane is a high energy renewable fuel which can be used as a substitute for other fuels such as charcoal and firewood used mostly in the rural areas of Ghana. ${ }^{37}$ The use of communal waste for anaerobic digestion reduces the over reliance on charcoal and firewood as fuel source. Another advantage is having a smoke and ash-free kitchen, so that women and children will no longer be susceptible to respiratory infections they cause. In addition, the gas produced, can be used in the production of heat and power generation using appropriate technologies. ${ }^{38}$ There are vast application which use combustion engines fuel with biogas. The conversion of methane produced from the waste substances to carbon dioxide by combustion reduces greenhouse impact by over 20 times. ${ }^{39}$ This decreases the impact of global warming caused by emission of greenhouse gases in landfill sites. Higher concentration of carbon dioxide in the biogas must be avoided since it contributes to the poor performance of biogas combustion engines. ${ }^{40}$ Studies indicate an increased exhaust emission of unburned fuel was identified to be within the range of $45-50 \%$ carbon dioxide. ${ }^{41}$ Due to the above predicament, technologies which involve absorption with water, PSA (Pressure Swing Adsorption), chemical absorption with amines, etc. are used for methane enrichment. ${ }^{42}$ Also, hydrogen sulphide and water (moisture) which are highly corrosive 
are removed. After purification the mean calorific value is enriched from about $20 \mathrm{MJ} / \mathrm{m}^{3}$ to approximately $39.8 \mathrm{MJ} / \mathrm{m}^{3}$ which gives more effective combustion to produce mainly, carbon dioxide and water. ${ }^{43}$ The digestate which is the by-product of anaerobic digestion is often rich in nutrients such as nitrogen and phosphate which could used as organic fertilizer and soil conditioner in neighbouring farming communities. Generally, by-products of biogas digestion are sold by commercial treatment facilities to sustain their operations. Currently there is scarcity of information in scientific literature on anaerobic codigestion of particularly in the tropical region of Ghana. Therefore, this study aims at investigating the effect of operating parameters such as $\mathrm{pH}$ value, hydraulic retention time (HRT) and temperature for an anaerobic co-digestion process of communal waste and cow dung to produce biogas in a batch scale. The results would determine the influence of the aforementioned operating parameters on anaerobic digestion of community waste. This would aid and ensure sustainable application of the use of communal waste for anaerobic digestion.

\section{Material and methods}

The biochemical methane potential (BMP) test was conducted to determine the potential of biogas on two (2) substrates in their fresh state, which were domestic waste; organic waste generated from the day to day activities of households and Market waste; organic waste generated from the community market.

\section{Material sampling}

Domestic and Market waste were collected from households and the local market at Kotei-Deduako in the Ashanti region of Ghana, serving as the feedstock. The choice of feedstock was due to its bioavailability in energy production. The inoculum (cow dung) was obtained from a cattle farm within the same municipality to provide the necessary bacteria for the anaerobic co-digestion process. It was kept in sealed Schott bottles and stored at $4^{\circ} \mathrm{C}$ prior to analysis.

\section{Characterization of feedstock and inoculum}

Domestic and Market waste were screened to remove unwanted particles such as plastics, metals etc. It was then milled with a blender
(Ok OMX 102-W, Germany) to a particle size of $5 \mathrm{~mm}$ for further analysis. Mechanical pre-treatment mainly chopping and milling have shown to be the most economical and relatively effective method to increase contact between the substrate and microorganisms. ${ }^{44}$ This was carried out to increase the surface area of the substrates during the $\mathrm{AD}$ process. The proximate analysis of the feedstock was performed as shown in Table 1; total solids (TS), moisture content (MC), volatile solids (VS) and ash contents (AC) using the standard methods. ${ }^{45,46}$ However, ultimate analysis was not included in this study. Standard procedures were carried out in the Laboratory using a precision balance (Kern PCB 3500-2, United Kingdom), a convection oven (VWR DRY-line oven, Pennsylvania), a muffle furnace (Nabertherm, Germany), a $5 \mathrm{~mm}$ sieve and a desiccator.

\section{Experimental design for the laboratory setup}

Table 2 represents the experimental design of the inoculum to feedstock selection for this study corresponding to eight (8) biodigesters. Three of the biodigesters were prepared with nutrient media to boost the biological activity. The nutrient media contained ammonium chloride $\left(\mathrm{NH}_{4} \mathrm{Cl}\right)$, potassium dihydrogen orthophosphate $\left(\mathrm{KH}_{2} \mathrm{PO}_{4}\right)$, disodium hydrogen phosphate dihydrate $\left(\mathrm{NaHPO}_{4} \cdot 2 \mathrm{H}_{2} \mathrm{O}\right)$, calcium chloride dehydrate $\left(\mathrm{CaCl}_{2} \cdot 2 \mathrm{H}_{2} \mathrm{O}\right)$, magnesium chloride hexahydrate $\left(\mathrm{MgCl}_{2} \cdot 6 \mathrm{H}_{2} \mathrm{O}\right)$ and iron (II) chloride tetrahydrate $\left(\mathrm{FeCl} .4 \mathrm{H}_{2} \mathrm{O}\right)$. After feeding the biodigesters at an optimal loading rate, the $\mathrm{pH}$ value in each biodigester was monitored within a desired range of 6.0-8.5. ${ }^{19}$ This optimal range was selected based on findings from existing studies involving $\mathrm{AD}$ process. The qualitative and quantitative analysis of biogas was assessed by a batch biochemical potential (BMP) test at mesophilic condition of $35 \pm 2^{\circ} \mathrm{C}$ for hydraulic retention time of 21 days using a biogas analyzer (Bluesens, Germany). The anaerobic digestion system is designed to qualitatively and quantitatively determine the volume of methane and carbon dioxide gases produced using a milligas counter and a UV detector respectively. The reactors were connected to the biogas analysers for online determination of methane concentration and volume of biogas during the entire period for the study.

Table I Composition of substrates

\begin{tabular}{|c|c|c|c|c|c|}
\hline Sample ID & Domestic waste (g) & Market waste (g) & Nutrient Medium (ml) & Distilled water $(\mathrm{ml})$ & Inoculum/ Cow dung (g) \\
\hline SI & 60 & $N / A$ & $N / A$ & 100 & $N / A$ \\
\hline S2 & $\mathrm{N} / \mathrm{A}$ & 60 & N/A & 100 & N/A \\
\hline S3 & 30 & 30 & 100 & $\mathrm{~N} / \mathrm{A}$ & $N / A$ \\
\hline S4 & 30 & 30 & $N / A$ & 100 & $N / A$ \\
\hline S5 & 50 & N/A & N/A & 100 & 10 \\
\hline S6 & $\mathrm{N} / \mathrm{A}$ & 50 & $N / A$ & 100 & 10 \\
\hline S7 & 50 & $N / A$ & 100 & $N / A$ & 10 \\
\hline S8 & $\mathrm{N} / \mathrm{A}$ & 50 & 100 & $\mathrm{~N} / \mathrm{A}$ & 10 \\
\hline
\end{tabular}


Table 2 Physiochemical properties of substrates

\begin{tabular}{|c|c|c|c|c|c|}
\hline Sample ID & $\mathrm{pH}$ & Moisture Content (\% w/w) & Total Solids (\% w/w) & Ash Content ( $\%$ w/w) & Volatile Solids (\% w/w) \\
\hline SI & 6.53 & 92.05 & 7.95 & 13.12 & 86.88 \\
\hline S2 & 6.98 & 91.87 & 8.13 & 11.86 & 88.14 \\
\hline S3 & 6.56 & 89.74 & 10.26 & 9.1 & 90.9 \\
\hline S4 & 7.04 & 90.88 & 9.12 & 8.93 & 91.07 \\
\hline S5 & 6.83 & 91.96 & 8.38 & 12.39 & 87.61 \\
\hline S6 & 6.88 & 89.36 & 10.64 & 14.69 & 85.31 \\
\hline S7 & 6.94 & 86.73 & 13.27 & 10.09 & 89.91 \\
\hline S8 & 6.93 & 88.97 & 21.03 & 8.66 & 91.34 \\
\hline
\end{tabular}

\section{Regression analysis and ANOVA}

A Response Surface Methodology (RSM) by the use of Central Composite Rotatable Designs (CCRD) was applied to analyse the effect of the variables such as $\mathrm{pH}(6.5-7.5)$, HRT (20-40) and temperature (35-40) and their relationship with the maximum concentration of methane produced. Design Expert 12.0.3.0 software (Statease, Minneapolis, MN, USA) was used for the CCRD and statistical analysis of variance (ANOVA), which resulted in 15 tests (1 factorial points, 2 -star points, and 3 central points, 1 response). The variables were set at three levels $-\alpha, 0$, and $+\alpha$ (where $\alpha=1.189$ ) in each case.

\section{Results and discussion}

A known quantity of inoculum and the feedstock were characterized according to standard methods. The results indicated a great methane potential as a significant biodegradable fraction exists in the feedstock. The effect of biochemical methane production on the biogas production process has been discussed below.

\section{Methane production}

As shown In Figure 1, a comparison among the eight different BMP tests in terms of percentage concentration of methane is shown. A lag phase was observed as the actual production of methane was detected after day 3 . This could be due to the time needed for microbial adaption to the set conditions such as temperature within the biodigesters. The sample S8 containing market waste and inoculum was observed to have produced the highest concentration of methane with a sharp rise from 16 to day $18\left(51 \% \mathrm{v} \mathrm{CH}_{4} / \mathrm{v}\right.$ biogas $)$. This may be due to the presence of cow dung (inoculum) as well as nutrients to aid the microbial activity of methanogens. Meanwhile, a deficiency of nutrient media was observed with a reduction of methane yield in sample S6 (31\% v/v biogas). This occurrence was similar with sample S5 and S7 recording 24 and $29 \% \mathrm{v} / \mathrm{v}$ methane respectively. Comparable to sample S8, S7 which was mainly household waste had a lower yield. However, in all the eight biodigesters, sample S2 yielded the lowest methane production over the 21 days period $(0.79 \% \mathrm{v} / \mathrm{v}$ biogas). The yield of methane in the rest of the biodigesters was not appreciable throughout the anaerobic digestion process. This could be attributed to the absence of nutrient media, cow dung (inoculum) and unfavourable or inadequate anaerobic digestion conditions within the biodigesters which yielded low methane concentration.

\section{Biogas production}

The relative cumulative biogas production from the eight biodigesters containing the substrates was observed as represented in Figure 2. It was evident that there was an exponential increase of biogas production for most of the digested substrates until day 10. Afterwards, specific samples such as S6, S7 and S8 containing cow dung (inoculum) had rapid increase in biogas production. In general biogas production became nearly constant for all the samples with the exception of S6 and S7 after the $19^{\text {th }}$ day. This is because the microorganisms responsible for the degradation during the $\mathrm{AD}$ process might have exhausted the volatile solids leading to the seizure of the entire process by the $19^{\text {th }}$ day. The results also show that on the $21 \mathrm{st}$ day, a higher biogas volume of $298 \mathrm{~mL}$ was produced from sample S6, followed by S2 and S4. Contrarily, with approximately $40 \mathrm{~mL}$, sample S1 and S5 produced the least amount of biogas. Also as shown in Figure 3, the average daily volume of biogas for the eight biodigesters labelled as sample IDs S1-8 was reported as 3, 9.74, 5.01, $9.94,2.99,14.19,1.94$ and $5.09 \mathrm{~mL} /$ day respectively.

\section{Regression analysis and ANOVA}

The experimental design used for response surface modelling was created using Design Expert 12.0.3.0 based on three factors; $\mathrm{pH}$, HRT and temperature. A Response Surface Methodology (RSM) through a Central Composite Rotatable Design (CCRD) was used. In general, the experimental data fitted to a quadratic- processing order. The validation of the accuracy of the quadratic model was tested with analysis of variance (ANOVA) with a confidence level (CL) of $95 \%$.

After employing the ANOVA multiple comparison test, it was found that the biogas model terms $\mathrm{P}, \mathrm{H}, \mathrm{PH}, \mathrm{PT}, \mathrm{P}^{2}, \mathrm{H}^{2}$ and $\mathrm{T}^{2}$ were significant $(\mathrm{P}<0.05)$. The validity of the model was assessed, and its statistical significance was determined by the Fisher's exact test (F-value). The goodness of fit of the model was checked by the coefficient of determination $\left(\mathrm{R}^{2}\right)$. The ANOVA values for the quadratic regression model obtained from the CCRD used is depicted in Table 3. 


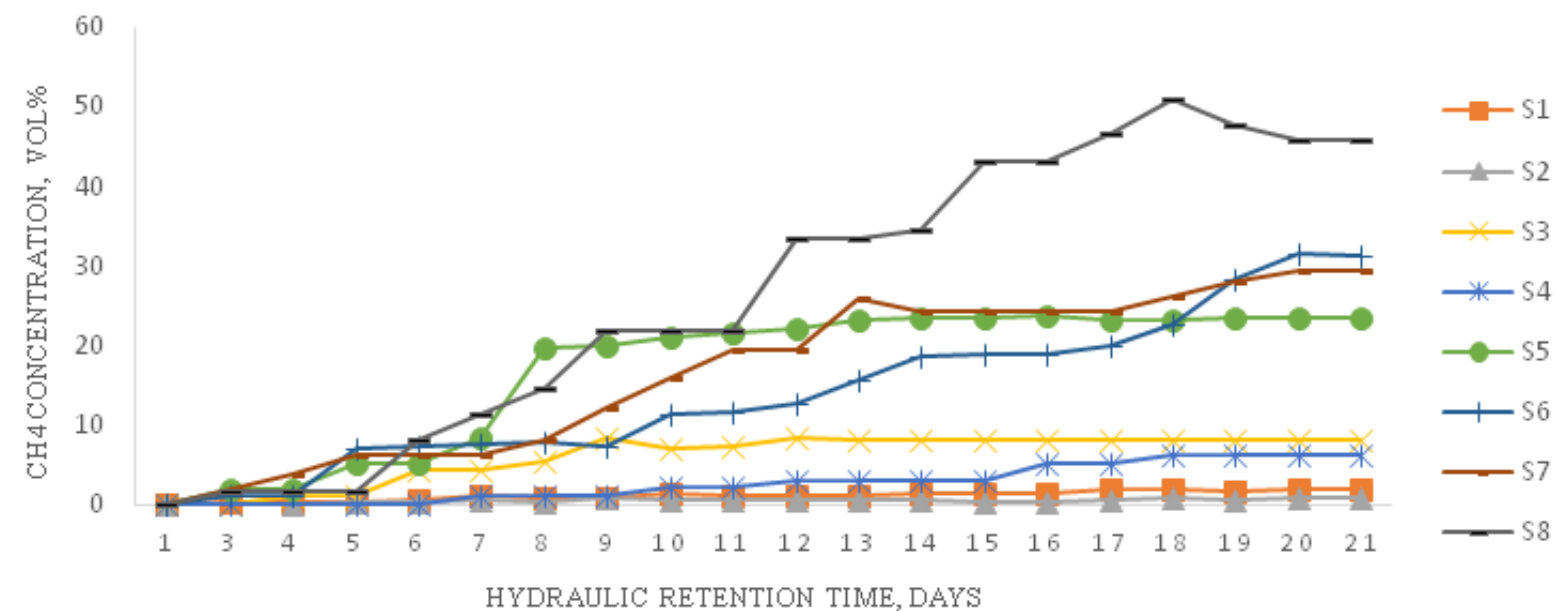

Figure I A graph of concentration (vol \%) of methane of substrates against time (days).

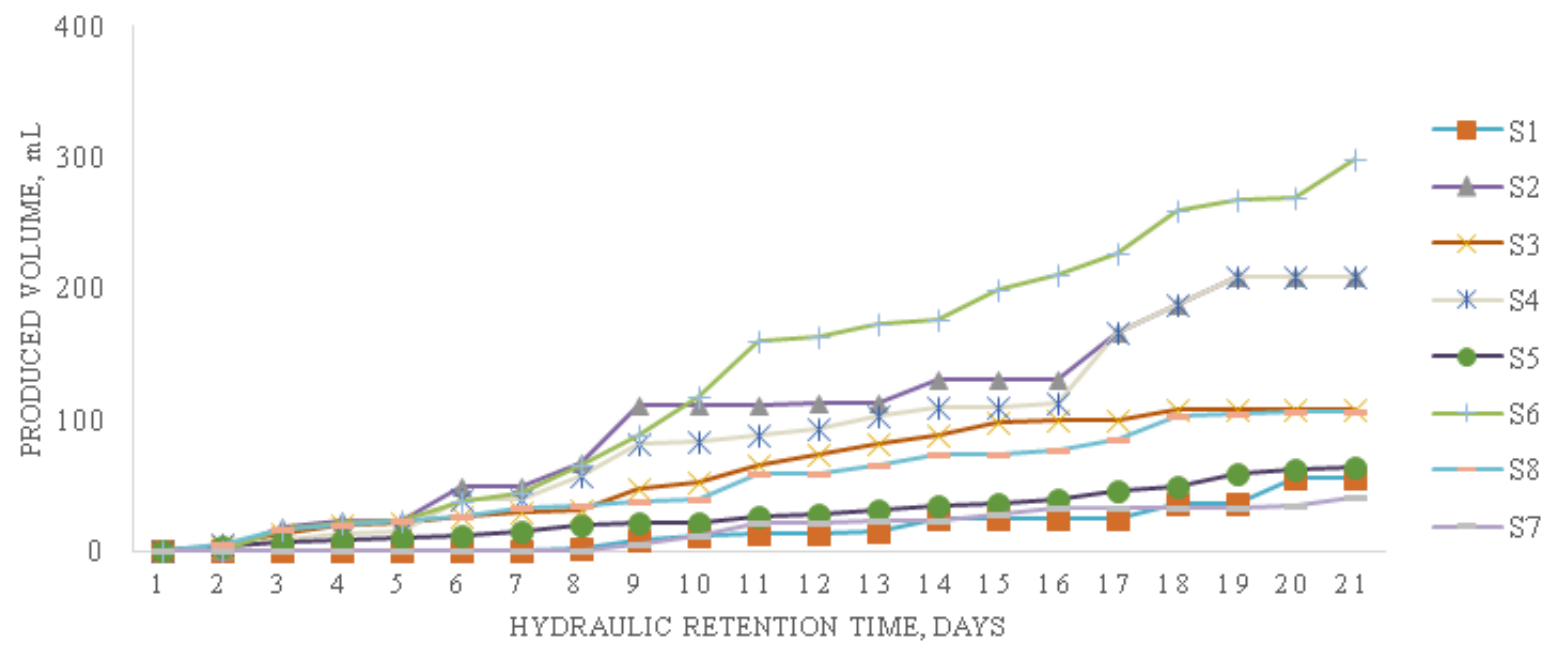

Figure $2 \mathrm{~A}$ graph of volume $(\mathrm{ml})$ of biogas produced by substrates against time (days).

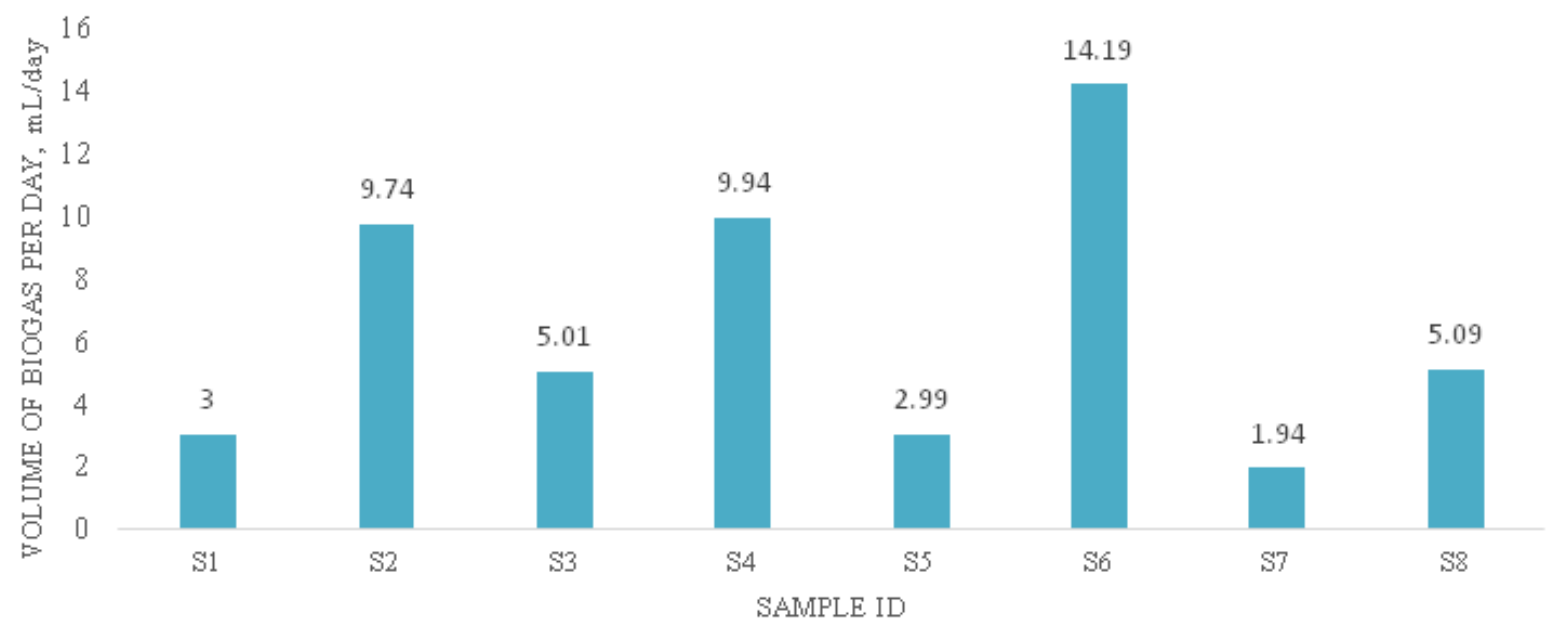

Figure 3 Average daily biogas production per substrate. 
Table 3 ANOVA results obtained to validate the model

\begin{tabular}{llll}
\hline Response & F-value & P-value & Comment \\
\hline Model & 12.66 & 0.0002 & significant \\
P-pH & 32.21 & 0.0002 & \\
H-HRT & 5.08 & 0.0479 & \\
T-Temperature & 3.79 & 0.0801 & \\
PH & 7.59 & 0.0203 & \\
PT & 5.94 & 0.035 \\
$\mathrm{P}^{2}$ & 28.95 & 0.0003 \\
$\mathrm{H}^{2}$ & 5.88 & 0.0357 \\
$\mathrm{~T}^{2}$ & 7.29 & 0.0223 \\
\hline
\end{tabular}

As shown on Table 3, the quality of methane produced is significantly affected by $\mathrm{pH}(\mathrm{P})$, HRT $(\mathrm{H})$ and Temperature $(\mathrm{T})$ of the substrate used. The model F-value of 12.66 infers the model is significant. There is only a $0.01 \%$ chance that an F-value this large could occur due to noise. Similarly, the P-values less than 0.0500 show model terms are significant. Values greater than 0.1000 indicate the model terms are not significant where model reduction was done to improve it. The interaction between the model terms result to an $\mathrm{R}^{2}$ of 0.9193 which is closer to 1 . This value signifies a high correlation existed between the actual values from the experiment and the predicted values.

The three-dimensional (3D) response surface plots which are graphical representations of the optimization of the anaerobic reaction variables and their contour lines are represented in Figures $4 \mathrm{a}-4 \mathrm{~d}$. From the figure, the retention time (HRT) is seen as an important factor contributing to the quality of methane produced from the substrate. This signifies, time has an effect on the efficiency of the anaerobic digestion process. Similar to the 3D plot (a), in 3D plot (c) it is observed that the $\mathrm{pH}$ value was a key contributing factor.

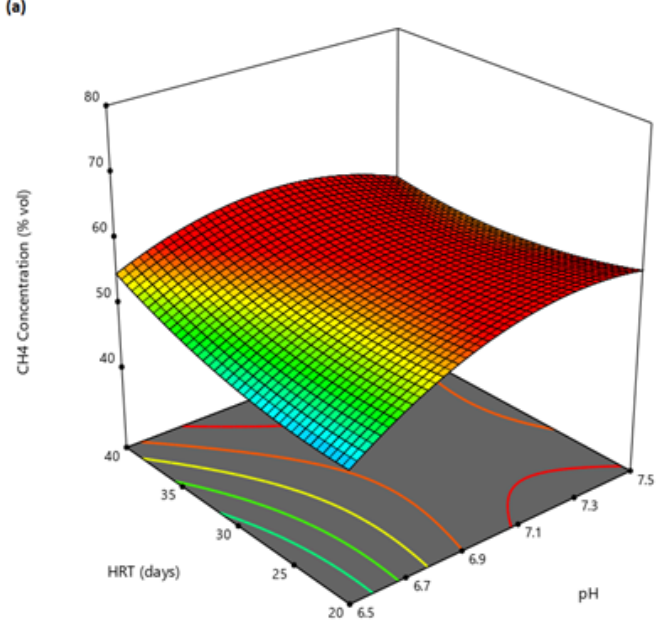

(c)

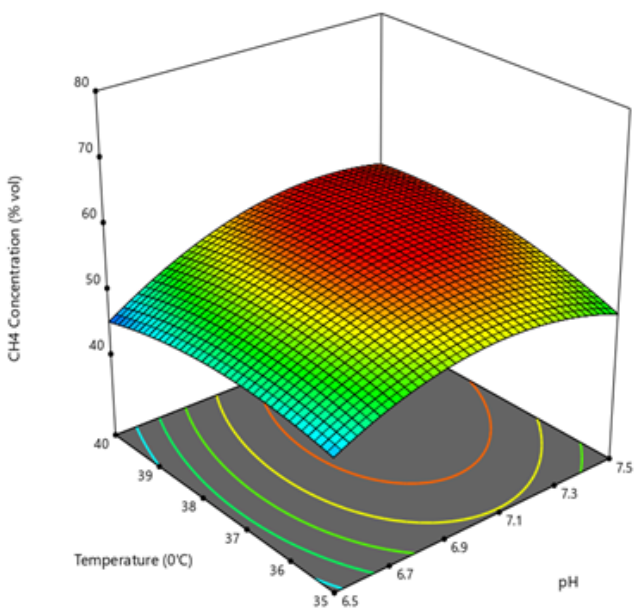

(b)

(b) 40

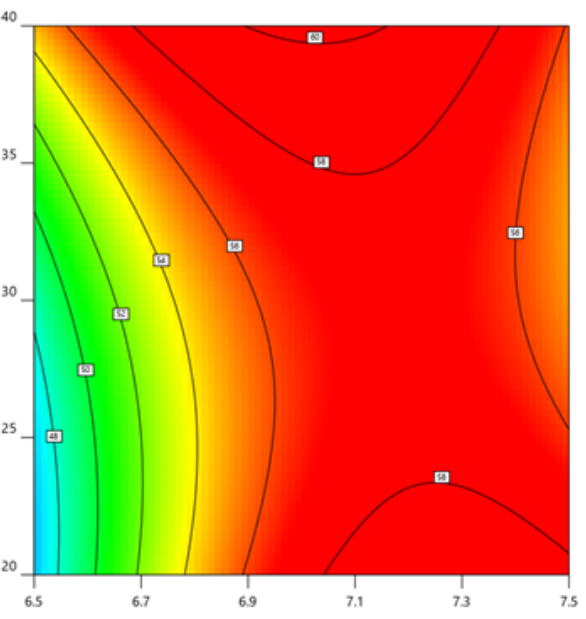

$\mathrm{pH}$

(d)

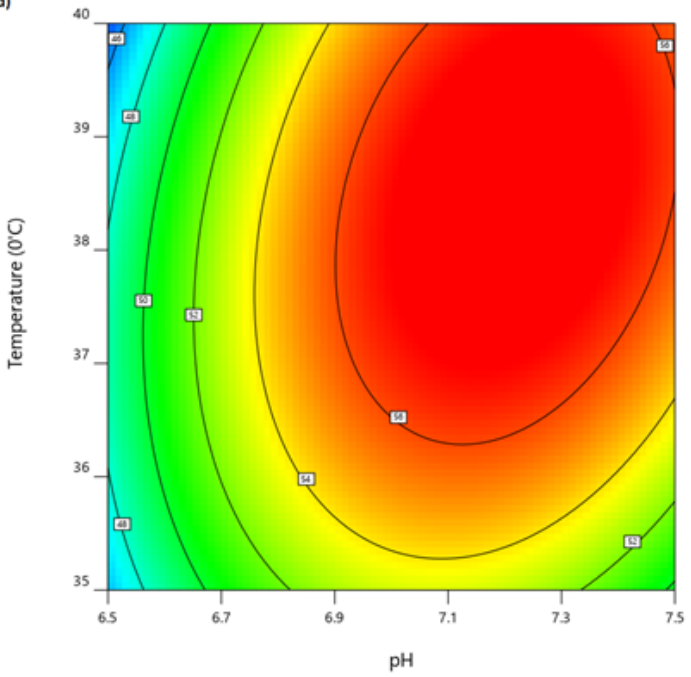

Figure 4(a-d) 3D and contour response surface plots for $\mathrm{CH}_{4}$ concentration showing the interactive effects of $\mathrm{pH}$ value, $\mathrm{HRT}$ and temperature. 


\section{Conclusion}

Solid waste from households and markets possess residual methane potential. According to the results obtained, both sources have high content of organic materials which could undergo anaerobic digestion under favorable conditions. Even though, the measured methane concentration of most samples was low relative to published methane yield, this could be due to short hydraulic retention time. The optimum methane content was found to be approximately $51 \% \mathrm{v} / \mathrm{v}$ of biogas yield. The ANOVA results indicated the methane concentration of biogas produced by the substrate is significantly affected by the $\mathrm{pH}$ value and hydraulic retention time of the anaerobic digestion process. Although the temperature range used do not have major influence on the concentrations of methane, a much lower or higher temperature affects other operating parameters of the digestion process.

As biogas is mainly methane and carbon dioxide, a pre-treatment technique and carbon dioxide purification method are necessary to increase the concentration of methane. Therefore, mixture of communal waste with cow dung as inoculum and nutrient media in adequate quantities could be a desirable alternative to mitigating associated problems in most societies. Furthermore, communal waste has the potential to produce biomethane, which could be utilized to lessen the dependency on fossil fuel derived energy and as an alternative energy source for combined heat and energy, which is ecofriendly. Also, this would reduce waste management issues faced by the region and the country as a whole thereby reducing the risk of poor sanitation induced diseases such as cholera, diarrhoea, dysentery, hepatitis A, typhoid and polio.Though seasonal availability of this type of feedstock (high in organic content) could be a challenge, codigestion with available biomass (e.g. manure) which has a higher biogas potential in substantial amount would be effective for continual operation of the process.

\section{Acknowledgments}

The authors are thankful to Mr. Gilbert Serlomey, Mr. Robert Aryeetey and Mr. Omari Agyapong for their immense support during the study.

\section{Funding}

None.

\section{Conflicts of interest}

The authors declare there are no conflicts of interest.

\section{References}

1. Samuel TA, Enoch AK. Solid Waste Management in Urban Areas of Ghana: Issues and Experiences from Wa. Journal of Environment Pollution and Human Health. 2014;2(5):110-117.

2. Asase M, Yanful EK, Mensah M, et al. Comparison of municipal solid waste management systems in Canada and Ghana: A case study of the cities of London, Ontario, and Kumasi, Ghana. Waste Management. 2009;29(10):2779-2786.

3. Miezah K, Obiri-Danso K, Kádár Z, et al. Municipal solid waste characterization and quantification as a measure towards effective waste management in Ghana. Waste Management. 2015;46:15-27.

4. Calvo F, Moreno B, Zamorano M, et al. Environmental diagnosis methodology for municipal waste landfills. Waste Manage. 2005;25(8):768-779.
5. Rana R, Ganguly R, Gupta AK. Impact of leachate from non-engineered landfill sites on groundwater quality-a case Study in Northern India. International Conference on Trends and Recent Advances in Civil Engineering - TRACE. 2016:183-191.

6. Bodzek M, Łobos-Moysa E, Zamorowska M. Removal of organic compounds from municipal landfill leachate in a membrane bioreactor. Desalination. 2006;198(2-3):16-23.

7. Akinbile OC, Yusoff SM. Environmental impact of leachate pollution on groundwater supplies in Akure, Nigeria. International Journal of Environmental Science and Development. 2011;2(1):81-86.

8. Islam RM, Razi AAK, Hasan RM, et al. Effect of leachate on surrounding surface water: case study in rajbandh sanitary landfill site in Khulna City, Bangladesh. Global Journal of Researches in Engineering. 2013;13(2).

9. Manyi-Loh CE, Mamphweli SN, Meyer EL, et al. Microbial anaerobic digestion (bio-digesters) as an approach to the decontamination of animal wastes in pollution control and the generation of renewable energy. Int J Environ Res Public Health. 2013;10(9):4390-4417.

10. Ayhan D, Osman T, Durmus K. Biogas production from municipal sewage sludge (MSS). Energy Sources, Part A: Recovery, Utilization, and Environmental Effects. 2016;38:3027-3033.

11. Babu RG, Kumar MG. An eco friendly solution to the food waste disposal. AIP Conference Proceedings. 2017;1859(1):020068-1020068-7.

12. Nayono ES. Anaerobic digestion of organic solid waste for energy production. Bauingenieur, Geo-und Umweltwissenschaften der Universität Fridericiana zu Karlsruhe (TH); 2009.

13. IEA. World energy outlook. 2006.

14. Paritosh K, Kushwaha SK, Yadav M, et al. Food waste to energy: an overview of sustainable approaches for food waste management and nutrient recycling. BioMed Research International. 2017;2017:2370927.

15. Sasse L. Biogas plants. Eschborn: Deutsche Gesellschaft für Technische Zusammenarbeit (GTZ) GmbH; 1988:2-61.

16. Tetteh E, Amano KOA, Asante-Sackey D, et al. Response surface optimisation of biogas potential in co-digestion of miscanthus fuscus and cow dung. International Journal of Technology. 2018;5:944-954.

17. Zabranska J, Pokorna D. Bioconversion of carbon dioxide to methane using hydrogen and hydrogenotrophic methanogens. Biotechnology Advances. 2017;36(3):707-720.

18. Olanrewaju OO, Olubanjo OO. Development of a batch-type biogas digester using a combination of cow dung, swine dung and poultry dropping. International Journal of Clean Coal and Energy. 2019;8(2):17.

19. Meegoda JN, Li B, Patel K, et al. A review of the processes, parameters, and optimization of anaerobic digestion. Int J Environ Res Public Health. 2018;15(2224):1-6.

20. Bergman EN. Energy contributions of volatile fatty acids from the gastrointestinal tract in various species. Physiol Rev. 1990;70(2):567590

21. Cheah YK, Vidal-Antich C, Dosta J, et al. Volatile fatty acid production from mesophilic acidogenic fermentation of organic fraction of municipal solid waste and food waste under acidic and alkaline $\mathrm{pH}$. Environ Sci Pollut Res. 2019:1-14.

22. Marinaro M. Li-ion batteries. Zentrum für Sonnenenergie und Wasserstoff Forschung Baden-Württemberg (ZSW); 2017:3-54.

23. Dhamodharan K, Ajay SK, Kondusamy D, et al. Pre-treatment and anaerobic digestion of food waste for high rate methane production - a review. Journal of Environmental Chemical Engineering. 2014;2(3):1821-1830. 
24. Mir MA, Hussain A, Verma C, et al. Design considerations and operational performance of anaerobic digester: a review. Journal Cogent Engineering. 2016;3(1)

25. Kiener A, Leisinger T. Oxygen sensitivity of methanogenic bacteria Syst Appl Microbiol. 1983;4(3):305-312.

26. Ariunbaatar J. Methods to enhance anaerobic digestion of food waste. Agricultural Sciences, Université Paris-Est; 2014.

27. Skiadas IV, Gavala HN, Lu J, et al. Thermal pre-treatment of primary and secondary sludge at $70^{\circ} \mathrm{C}$ prior to anaerobic digestion. Water Science. 2005;52(1-2):161-166.

28. Franke-Whittle IHWA, Ebner C, Insam H. Investigation into the effect of high concentrations of volatile fatty acids in anaerobic digestion on methanogenic communities. Waste Manag. 2014;34(11):2080-2089.

29. Rabii A, Aldin S, Dahman Y, et al. A review on anaerobic co-digestion with a focus on the microbial populations and the effect of multi-stage digester configuration. Energies. 2019;12:1106.

30. Mao C, Feng Y, Wang X, et al. Review on research achievements of biogas from anaerobic digestion. Renewable and Sustainable Energy Reviews. 2015;45:540-555.

31. Sambo AS, Garba B, Danshehu BG. Effect of some operating parameters on biogas production rate. Renewable Energy. 1995;6(3):343-344.

32. Sarono S, Suparno O, Suprihatin S, et al. The performance of biogas production from pome at different temperatures. International Journal of Technology. 2016;7(8):1413-1421.

33. Asante-Sackey D, Tetteh EK, Nkosi N, et al. Effects of inoculum to feedstock ratio on anaerobic digestion for biogas production. Int $J$ Hydro. 2018;2(5):567-571.

34. Monnet F. An introduction to anaerobic digestion of organic wastes Final Report; 2003.

35. Igoni HA, Abowei MFN, Ayotamuno MJ, et al. Effect of total solids concentration of municipal solid waste on the biogas produced in an anaerobic continuous digester. Agric Eng Int CIGR Ejournal. 2008.
36. Getahun T, Gebrehiwot M, Ambelu A, et al. The potential of biogas production from municipal solid waste in a tropical climate. Environ Monit and Assess. 2014;186(7).

37. Kemausuor F, Ivan N, Mackenzie G. Prospects for bioenergy use in Ghana using long-range energy alternatives planning model. Energy. 2015;93(1):672-682.

38. Tetteh EK, Amano OAK, Asante-Sackey D, et al. Biochemical methane potential (BMP) of miscanthus fuscus for anaerobic digestion. International Journal of Scientific and Research Publications. 2017;7(12):434-439.

39. Benaissa K, Dadamoussa $\mathrm{B}$, Bendraoua A. Biogas and $\mathrm{CH} 4$ quality and productivity by co-digesting drometary dung with kitchen waste and sewage sludge water under mesophilic conditons. Journal of Fundamental and Applied Sciences. 2017;9(3):1701-1717.

40. Saiful B. Effect of carbon dioxide on the performance of biogas/diesel duel-fuel engine. Renewable Energy. 1996;9(1-4):1007-1010.

41. Hobson PN, Bousfield S, Summers R. Methane production from agricultural and domestic wastes. Applied Science. 1981. 152 p.

42. Mirsada N, Removal of carbon dioxide from biogas. Department of Chemical Engineering, 2006:1-5.

43. Shekhar CS, Kandpal C. A framework for the financial evaluation of household biogas plants in India. Biomass. 1990;23(1):39-53.

44. Basaria P, Priadi RC. Influence of organic fraction of municipal solid waste particle size on biogas production. International Journal of Technology. 2016;7(8):1431-1437.

45. APHA. Standard methods for the examination of water and wastewater. Washington DC, USA; 1998

46. Amano OAK, Offei FD, Adom E, et al. Determination of biogas content in biomass after anaerobic digestion. 2017:1-17. 